\title{
Author as a Medium: Strategies of Embodiment of Text in Poetry Slam
}

\author{
Agata Kolodziej \\ Jagiellonian University, Cracow, Poland
}

\begin{abstract}
Dana Gioia in her publication Disappearing Ink: Poetry at the End of Print Culture, draws attention to the increasing popularity of oral forms of poetry-rap, cowboy poetry, poetry slams and performance poetry. According to Gioia, transformation of author "from an invisible creator of typographic language to a physical presence performing aloud”, leads to formulation of a strong antithesis for Barthes' “death of the author”, namely “death of the text”. In her paper, Gioia assumes that the appearance of the author in his physical presence on stage performing text is equivalent to rebirth of an author and his restoration of power over the meaning of text. This assumption results from a strong division between the process of production and the process of reception of text, which maintains a strong opposition among author, text, and reader. This paper presents slam poetry as an event, during which prepared, written text merges with spoken word susceptible to voices from the audience. This fusion leads to rejection of strong division between production and reception of text and thus between author and reader making all of them participants. Print medium is replaced with living body, which responds to the audience and their reception of text. Text is no longer perceived as an artifact, but as a performative process focused on interaction between participants, which cannot exist outside the event.
\end{abstract}

Keywords: slam poetry, author, performative process, reception of text

\section{Introduction}

Gioia (2003) in article Disappearing Ink: Poetry at the End of Print Culture, initially assumes that print has ceased to be the primary medium of poetry. As evidence for this changes, she sees the increasing popularity of oral poetry forms such as rap, cowboy poetry or slam. It leads her to formulation of a strong antithesis for Barthes' “death of the author” (Barthes, 1977, pp. 142-146), namely “death of the text”. She argues

As readers turn into viewers and listeners, they naturally approach the new poetry in ways conditioned by television and radio [...], it transforms the identity of the author from writer to entertainer, from an invisible creator of typographic language to a physical presence performing aloud [...]. Roland Barthes, a creature of print culture, saw the world as a text and announced $<<$ the death of the author $>>$. Anyone attentive to the new popular poetry sees the antithesis-the death of the text. American culture conditioned by electronic media and a celebrity culture based on personalities has given birth to a new kind of author, the amplified bard. (Gioia, 2003, p. 29)

When Gioia announces in her article the end of the dominance of print culture towards spoken art gaining

Agata Kolodziej, M.A., Ph.D. Candidate in Department of Performative Studies, Jagiellonian University. 
more and more popularity, she simplifies Barthes' text. This is because she believes that the mere physical presence of the author on the stage, is tantamount to killing his textual counterpart, and further throughout the text.

Somers-Willett comes to a similar recognition in her book The Cultural Politics of Slam Poetry: Race, Identity and the Performance of Popular Verse in America. Examining the problem of identity building by African-American slam poets she limits slam poetry to creativity centered around the identity-building subject apart from all other possible implementations or forms. The narrowing allows her to make the following conclusion: "In its emphasis on the author's proclamation of self, what slam poetry offers is the antithesis of philosopher Roland Barthes's $<<$ death of the author $>>$ - the idea that the text and the author are unrelated" (Somers-Willett, 2009, p. 34). Both researchers seem to forget that the argument put forward by the French philosopher was concerned only with the text. It is important to point out that a poetry slam is a form of event, so in his case it is difficult to talk about strict divisions of categories of sender/author, recipient/reader and text. Thus, the reference to them during slam poetry analysis should not be done on the basis of such a simple ratio. Shifting of the written text from the position of imperative medium is not synonymous with a negation of all that Barthes wanted to say in his article.

The purpose of this article is an indication of the new function of the author-slammer that embodying the text on the stage becomes a medium that allows the participants direct interaction with the text and affecting its final shape, and by that blurring the boundary between the production and reception of text. Starting from the postulates made in the famous text of Roland Barthes and his reception, I would like to point out the performative dimension of slam poetry events during which text still exists, but through the mediation of the author as the living body. Therefore, it is an unsustainable form, prone to influences from the audience, which allows all participants, including the author, formulation of the shared process of production of meaning, which is based on active participation of both: the author and the audience.

Barthes in The Death of the Author maintains a strong opposition between author, text and reader. In this configuration, the author is known as the source of sense-the one, who puts meaning into the text. He is the book's past. As Barthes writes: "The Author is thought to $<<$ nourish $>>$ the book, which is to say that he exists before it, thinks, suffers, lives for it, is in the same relation of antecedence to his work as a father to his child" (Barthes, 1977, p. 145). The author becomes the instance guaranteeing coherence of meaning. According to Barthes, this category should be replaced by a scriptor, who

...is born simultaneously with the text, is in no way equipped with a being preceding or exceeding the writing, is not the subject with the book as predicate; there is no other time than that of the enunciation and every text is eternally written here and now. (Barthes, 1977, p. 145)

Author of S/Z rejects understanding of writing as an operation of recording. He replaces it with Austin's notion of performative use. Source of writing is no longer in the author, but in language. The author becomes a clearly textual creature. Text becomes a space without any primary sense, "a tissue of quotations drawn from the innumerable centers of culture” (Barthes, 1977, p. 146). The main aim of Barthes' article is to shift the emphasis from category of author to reader. Death of the author becomes a necessary sacrifice. It can make possible the birth of reader as a category combining in her actions all traces and references from which text was made. In other 
words, it opens the text to the creative participation of the reader.

Given this way of reading The Death of the Author, it seems wrongful to reject all of the thesis of Barthes' text in the context of the contemporary oral practices. Barthes, Gioia, and Somers-Willett divide the process of production and the process of reception of text. A strong dichotomy between author- "creator of text and author" - scriptor, textual creation, leads to a simplified assumption adopted by researchers that the appearance of the author in his physical presence on stage is proof enough that the author is alive and well” (Somers-Willett, 2009, p. 34). Meanwhile, events such as poetry slam shows that restoration of categories is not that simple. Poetry slam is a competition in which anyone can perform. Performances are judged on a numerical scale by previously selected members of the audience. Slam requires from poets to perform their original work, but it does not mean that the slammer standing on the stage is equivalent to the "author" speaking in performed text. Performative character of poetry slam overcomes the opposition between the category of author, text and reader indicating their equal involvement in the formation of the event.

The problem of author's death described in such fundamental texts as Barthes' article is the theory that has been analyzed many times, and even the author himself, in later texts has verified this theory. Therefore, this article is not intended to be a direct polemic with Barthesian theory and treats it only as a starting point for the delineation of the problem of the author in slam poetry. However, it seems reasonable to start with a brief outline how the issue has evolved and how it has been modified over recent years. Zawadzki (2006) in article Autor. Podmiot literacki identified three problem areas around which the theoretical reflections were focused in an attempt to restore the category of author: Barthes' philosophy of the trace, Foucault's "self-writing" and concepts focused on ethical or ethical and empirical dimension. The first of mentioned areas assumed a trace understanding of subjectivity. In his book, Sade, Fourier, Loyola, Barthes writes: "For if, through a twisted dialectic, the Text, destroyer of all subject, contains a subject to love, that subject is dispersed, somewhat like the ashes we strew into the wind after death” (Barthes, 1989, pp. 8-9). Barthes resigns from universal, institutional subject for the benefit of a private, physical one, who communicates his individual experiences via text traces. Foucault understands the act of writing as an act of identity construction advocating the concept of narrative subjectivity. The third area is based on subjectivity saturated empirically-exposing conditions of ethnic or gender of the subject. As Zawadzki suggests, a feature combining this three ways of thinking is a lack of dualistic perception of the problem:

The feature that is common to all three mentioned directions, paths which subject returns today to the text, is, it seems, an attempt to go beyond the radical opposition of $<<$ strong $>>$ presence and an equally $<<$ strong $>>$ absence of the author as essentialist, fully autonomous subject (...) and $<<$ author $>>$ as a blank space of structure. (Zawadzki, 2006, p. 245)

The author returns to the text, but not in its traditional form as a person conditioning the sense of the text, as Gioia would like. Once again we see the death of institutional form, not the category itself. Conservatism of all these theories described by Zawadzki is based on consistently strong separation of aesthetic production of aesthetic reception, which prevents the meeting of author and recipient. During poetry slam this opposition is undermined by the collective nature of an event. The author is also the recipient, and the recipient has an impact on the shape of text which embraces its performative form.

Slam as a poetry competition offers more possibilities of interference in configuration of people 
participating in the event. Roles are not imposed from the beginning of the event. Participants entering the slam shall choose whether they want to try to appear as artists during the evening. By signing up on the list of performers they report themselves and their work as a candidate for evaluation. But they remain as a part of the audience until they are called by the Master of the Ceremony. From this moment they have exactly three minutes to perform their poem. After each performance audience vote. If the slammer manages to collect enough points he can come back on stage in the next round to present more of his works. However, after every show, the slam poet returns to the audience to, as its member, take part in the event. The line dividing the author and the viewer becomes indistinct. Each participant may occur on stage, but also each of the performers is situated on the position of the recipient for most of the evening. Dialogical structure allows the audience to participate in the creation of a text by a comment, applause or a loud resistance. The slammer should be constantly aware of the audience surrounding him. The need to reach out to a wider and more diverse public forces poets to make many sacrifices. Poetry presented by them must immediately impact on the listener. During the three minute show there is no time for a long meditation on the meaning of the poem. Comedy, parody, insult, sensitivity —everything can be used to attract the attention of those who are present. O'Keefe Aptowicz: "Slam in general (...), remain a Noah's Ark with persons of every ethnicity, every sex, every political view shouting and whispering onstage" (2008, p. xiv). Poets are encouraged to do whatever they want, and thus go beyond the usual concepts of poetic evenings.

Pluralism and diversity govern the course of the meeting. Text loses priority to presentation. Instead of a finished work of art as artifact, poetry slam presents a dynamic event, which is produced between the performers and the audience. The slammer on the stage isn't an author-guarantor of meaning and authenticity, he is the embodiment of the text, which he performs. Print medium is replaced by living body, which responds to the audience and their reception of text. As in the literary tradition the subject speaking in a slam poem is not always synonymous with the writer, located in the past of the text. The "I" of the poem doesn't have to be equal to the "I" appearing on the stage, even if it is known that poets performing during the slam have to be the authors of texts presented on stage.

Fischer-Lichte (2008) characterizing the changes that entails the aesthetics of performativity pays particular attention to redefinition of concepts such as dichotomy of materiality and semioticity. In performative acts this terms lose their polarity and begin to oscillate around each other. In the light of such methodologies such as semiotics and hermeneutics, each material element of the work of art becomes a sign, because in a work of art there is nothing beyond the structuralist relationship of signifie and signifiant. During the slam, direct impact on the viewer is most important. Materiality precedes any attempt to give semioticity, because the body-not the letter, mediates text. Reactions caused by activities have priority here. As Fischer-Lichte writes,

The materiality preceded all attempts to interpret them beyond their self-referentiality. It did not yield to and dissolve into a sign but evoked a particular effect on its own terms. This very effect (...) set the process of reflection in motion for the audience. (Fischer-Lichte, 2008, p. 18)

This kind of materiality is present during the slam competition. The rapid course of events does not allow the listener to devote too much time to reflection. They must make a momentary decision whether to side with the artist and what he is trying to say, or turn against him. The words spoken by slammer present themselves to the 
audience in its elusiveness. It is not possible to return to the text once heard. Instead of the depth of the text as a result of long-term reading, reader gets a multiplicity of impulses, whose impact should be immediate.

Recognizing the importance of the audience, slam poets carefully select their text's topic, tone of voice and language depending on the type of the audience. Some of them present only sketches of his works, editing them during the show. Changes are sometimes made as an effort to refresh and re-use the same line for the next slam competition. As a result of these procedures, it is difficult to speak about the originality of the poem. Somers-Willett writes: "slam poems have multiple <<original moments $>>$ as they are performed over and over again and change both in performance and content to suit different live audiences” (2009, p. 26). Text loses its original form and becomes a dynamic process, which does not refer to anything that could guarantee stability of sense. Once the text is no longer mediated by the print artifact, along with constancy it loses direct reference to the source, and thus the author ceases to be an instance guaranteeing its meaning. The author becomes an alternative for print, mediating the text through his physicality, which cannot be hidden behind any kind of props and costumes. The only thing that is available for the slammer during the performance is himself-his voice, expression, and gestures, which should be used to interact with the audience. The slammer wanting to arise during the event must correspond with everything that is happening around him. Early preparation of text and automatic recitation of it very rarely ends with the immediate approval of the audience during local slam events. At the slam, in the absence of its permanent, invariable essence and diversity created through contextualization, an event occurs. Material coexistence of performers and spectators creates relationships "in between":

Through their physical presence, perception, and response the spectators become co-authors that generate the performance by participating in the $<<$ play $>>$. The rules that govern the performance correspond to the rules of a game, negotiated by all participants-actors and spectators alike; they are followed and broken by all in equal measure. (Fischer-Lichte, 2008, p. 32)

Community of performers and the audience occurring at poetry slam allows all participants to create sense during the event. Sense, which is individual and unrepeatable.

Strong opposition between author, text and reader results in an eternal battle between these three categories for power over the meaning. Domination of one must be equivalent to reduction of others. Therefore, as Barthes writes, "the birth of the reader must be at the cost of the death of the Author". The role of the author must be reduced if the reader wants to become a co-author of the text. When Gioia restores the power of the author, it must happen at the expense of the text as a guarantor of meaning. But text is understood by her only as a printed artifact. The community of performers and audience at a slam poetry event leads to the loosening of the rigid division of authors and viewers/readers. This produces a new model of artist—slam poet that is not present on the stage as an author - a guarantor of meaning and authenticity of text, but he becomes a medium, an embodiment of the text, which he performs. Print medium is replaced with living body, which responds to the audience and their reception of text.

\section{References}

Barthes, R. (1977). Image music text. London: Fontana Press.

Barthes, R. (1989). Sade, Fourier, Loyola. Barkley and Los Angleles: University of California Press.

Fischer-Lichte, E. (2008). The transformative power of performance: A new aesthetics. New York: Routledge.

Gioia, D. (2003). Disappearing ink: Poetry at the end of print culture. The Hudson Review, 56(1), 21-49. 
O’Keefe Aptowicz, C. (2008). Words in your face: A guided tour through twenty years of the New York City poetry slam. New York: Soft Skull Press.

Somers-Willett, S. B. A. (2009). The cultural politics of slam poetry: Race, identity and the performance of popular verse in America. Michigan: University of Michigan Press.

Zawadzki, A. (2006). Autor. Podmiot Literacki. Ed. Michat Paweł Markowski, Ryszard Nycz. Kulturowa teorie literatury. Gtówne pojęcia i terminy (pp. 217-245). Cracow: Universitas. 2006. 